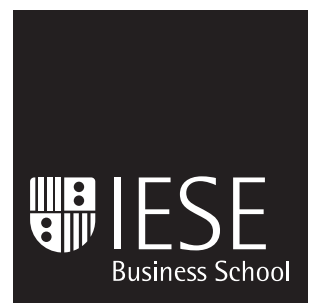

SP-SP

Working Paper

WP no 648

September, 2006

University of Navarra

\title{
SOCIAL NORMS AND HOUSEHOLD TIME ALLOCATION
}

\author{
Cristina Fernández \\ Almudena Sevilla-Sanz
}

IESE Business School - University of Navarra

Avda. Pearson, 21 - 08034 Barcelona, Spain. Tel.: (+34) 932534200 Fax: (+34) 932534343

Camino del Cerro del Águila, 3 (Ctra. de Castilla, km 5,180) - 28023 Madrid, Spain. Tel.: (+34) 913570809 Fax: (+34) 913572913

Copyright ${ }^{\odot} 2006$ IESE Business School. 
The Public-Private Center is a Research Center based at IESE Business School. Its mission is to develop research that analyses the relationships between the private and public sectors primarily in two areas: regulatory (the effects of regulation on private economic activity) and contractual (the total or partial transfer of public services to the private sector). Research results are disseminated through publications, conferences and colloquia. These activities are aimed to foster cooperation between the private sector and public administrations, as well as the exchange of ideas and initiatives.

The sponsors of the SP-SP Center are the following:

- Accenture

- Ajuntament de Barcelona

- Official Chamber of Commerce, Industry and Navigation of Barcelona

- BBVA

- Diputació de Barcelona

- ENDESA

- Garrigues, Abogados y Asesores Tributarios

- Catalan Government (Generalitat de Catalunya)

- Grupo MSD

- Telefónica

- T-Systems

- VidaCaixa

The content of this publication reflects the conclusions and findings of the individual authors, and not the opinions of the Center's sponsors. 


\title{
SOCIAL NORMS AND HOUSEHOLD TIME ALLOCATION
}

\author{
Cristina Fernández $z^{* *}$ \\ Almudena Sevilla-Sanz ${ }^{* * *}$
}

\begin{abstract}
Economic theories of the household predict that increases in female relative human capital lead to decreases in female housework time. However, longitudinal and cross-sectional evidence seems to contradict this implication. Women's share of home time fails to decrease despite increases in women's relative earnings. The literature has proposed social norms on the household division of labor as an alternative explanation. We use the 2002-03 Spanish Time Use Survey (STUS) to explore the presence of social norms associated to the household division of housework and childcare. First, we observe that wives that earn more than their husbands still undertake more than 50\% of housework and childcare. Second, we find that a woman's relative share of housework decreases as her relative earnings increase, but only up to the point when she earns the same as her husband. Finally, independently of the definition of childcare, the relative time devoted to childcare does not vary with spouses' relative earnings. All these findings suggest that social norms might be an important factor in the division of household time.
\end{abstract}

** Research Assistant, IESE

*** University of Essex

JEL Classification: D13, J0, J1, Z13

Keywords: household production and intrahousehold allocation, time allocation, social norms, Spain. 


\section{SOCIAL NORMS AND HOUSEHOLD TIME ALLOCATION*}

\section{Introduction}

Comparative advantage and bargaining theories of the household predict a more egalitarian allocation of time within the household as female human capital increases. In the comparative advantage framework specialization is efficient, and the spouse with the lowest opportunity cost (i.e. the lowest human capital or the highest home productivity) contributes the most to household production and the least to market work (Becker, 1991). Bargaining theories reach the same conclusion but are based on the concept of threat points determined by either the cost of filling out of marriage (McElroy and Horney, 1981) or of a non-cooperative marriage (Lundberg and Pollak, 1993). ${ }^{1}$

However, longitudinal and cross-sectional evidence seem to suggest that women's share of home time fails to decrease despite increases in women's earnings. At the longitudinal level there is vast evidence from time-use surveys that despite the increase in female labor force participation, time devoted to housework by men has changed very little in the last decades, and thus specialization within the household has remained fairly unchanged (Aguiar and Hurst, 2006). At the cross-sectional level Hochsehild and Machung (1989) first showed some qualitative evidence pointing to the fact that when a wife works more hours than her husband outside the home, she still undertakes a larger share of housework. In the same vein Akerlof and Kranton (2000) corroborate Hochsehild findings using PSID data.

Traditional theories of the household can explain the evidence above by assuming either that, women have a higher comparative advantage in household production or that women derive a higher utility from housework. However under these assumptions we would not be able to explain the empirical regularity that women with higher earnings than their husbands do not only do relatively more housework than them (as in Akerlof and Kranton's findings), but also do relatively more housework than women whose earnings are lower than their husbands. In fact empirical findings for the US and Australia suggest that a woman's relative share of

\footnotetext{
*The authors are greateful to Daniel Hamermesh and Manuel F. Bagues for their comments. We are also thankful to participants at the Joint Empirical Social Science Semminar at ISER, participants at the 2006 IZA-SOLE Transatlantic Meetings of Labor Economists and participants at the 2006 ESPE Congress in Verona. Remaining errors are of our exclusive responsibility.

${ }^{1}$ Chiappori (1992) and Browning and Chiappori (1997) unified both set of theories into a "collective" approach to the household, where efficiency in the household maximization problem is secured due to spousal transfers of private consumption.
} 
housework decreases as her relative earnings go up, but only up to the point when she contributes the same as her husband to the family income. When her contribution to the total household income goes beyond fifty percent, her housework share increases as her earnings go up (Brines, 1994), (Greenstein, 2000), (Gupta, 1999), and (Bittman et al., 2001).

Social scientists have turned to social norms to explain these empirical regularities. ${ }^{2}$ Akerlof and Kranton suggest an economic model of identity to explain why women undertake a greater share of housework than their husbands even when they work more hours and have higher earnings than them. In their model a husband looses identity when his wife earns more than him because of the prescription held by most men that they should earn more than their wives. Equality in utility is restored when the wife undertakes more housework than her husband given the prescription that men should not do women's work at home. In a similar fashion the sociological literature argues that when men earn less than their wives a gender norm violation occurs, thus either, the wife, the husband or both move to more traditional behavior in the realm of housework in order to neutralize this deviance. This would explain why women that earn more than their husbands not only devote more time to household chores than them, but also do relatively more housework than women who earn less than their husbands. This neutralization effect is what has been called in the literature doing gender.

The 2002-2003 Spanish Time Use Survey (STUS) is used in this paper to explore the presence of social norms associated to the household division of labor. We extend previous studies by not only looking at how husband and wife allocate their time to household chores (or housework), but also the household division of childcare time. Spain is the perfect example to use in this context as it is a country where gender roles are deeply entrenched. ${ }^{3}$ The STUS has two main advantages over other time use data sets. First it is diary data, i.e. individuals record each activity during the 144 ten-minute interval of the day. A vast amount of evidence support the reliability of diary information over ex-post stylized questions on total time spent in any given activity (Juster and Stafford, 1991). Second, the STUS is advantageous over other diary surveys such as the American time use diary survey because it not only contains diary information on the respondent but also on the spouse. This piece of information is crucial for the construction of a measure of specialization within the household.

We find support for the notion of social norms upon the division of housework the way that has been characterized in the literature. First, similar to Akerlof and Kranton, we observe a high level of specialization within the household, with women that earn more than their husbands still undertaking about 70\% of all housework and childcare. Second, we find that a woman's relative share of housework decreases as her relative earnings increase only up to the point when she earns the same as her husband, but then it remains constant. Finally, we use detailed description of childcare activities in the diary data to help us conceptualize childcare time. Detailed diary data allow us to distinguish between childcare that might be conceptualized as housework (either because it can be easily outsourced or no direct utility is derived in the margin) and childcare conceptually closer to leisure. We find that, independently of the definition of childcare, the relative time devoted to childcare does not vary with spouses'

\footnotetext{
${ }^{2}$ Although highly interesting, the formation and enforcement of social norms is beyond the scope of this paper. See Burda et al. (2006) for the use of social norms regarding the coordination of leisure activities to explain the fact that men and women total paid and unpaid work hours are the same over time and across countries.

${ }^{3}$ For example, Alvarez and Miles show that the unequal allocation of household time in two earners Spanish couples persists after observable characteristics are taken into account (Alvarez and Miles, 2003).
} 
relative earnings. All these findings seem to contradict traditional theories of the household and suggest that social norms might be at the root of division of household time.

The paper is organized as follows. Section 2 describes the data set used in the analysis. Section 3 specifies the empirical methodology. Section 4 presents the empirical results and discusses alternative interpretations to our findings. Section 5 concludes.

\section{2002-2003 Spanish Time Use Survey (STUS)}

The data used for the empirical analysis is drawn from the 2002-2003 Spanish Time Use Survey. The STUS is part of the Harmonized European Time Use Surveys (HETUS) launched by the EU Statistics Office (Eurostat). It consists of a representative sample of 20,603 households and contains information on daily activities by means of the completion of a personal diary and household and individual questionnaires. The sample is evenly distributed over the year and the week in order to accurately represent time use patterns during all the days of the week.

The instrument of the survey is based upon a diary of activities, where all members of the household, 10 years old and over complete on a selected day (the same day for all members of the household). An extensive literature confirms the reliability and validity of diary data and its superiority over other time-use surveys based on stylized questions, which ask respondents to estimate time in activities on a "typical day" (Robinson, 1985) and (Juster and Stafford, 1991). The diaries time frame is 24 consecutive hours (from 6:00 a.m. in the morning until 6:00 a.m. the following day) and is divided into 10 minute intervals. In each of the intervals, the respondent records a main activity and a secondary activity (carried out simultaneously with the primary activity), whether the activity was performed in the company of a child under 10 years old, another member of the household or another adult, and the location where the activity took place. ${ }^{4}$ Activities are coded according to a harmonized list of activities established by Eurostat and are grouped into 10 major categories: personal care, work, studies, household and family, volunteer work and meetings, social life and recreation, sports and open air activities, hobbies and games, means of communication, and non-specified travel and use of time. The STUS proves particularly useful for our study since, unlike other recent diary-based time use surveys like the American Time Use Survey (ATUS), the STUS contains information on time devoted to household production by both spouses. This information is crucial when the variable of interest is specialization within the household.

Due to the novelty of this data set, Table 1 presents a comparison between the Spanish Time Use Survey and the Spanish Labor Force Survey (EPA), a well-known representative panel data set of the Spanish labor market. The main demographic and economic variables in both data sets resemble each other, although the education distribution is somewhat different between the two surveys. However, labor indicators are remarkably similar in both data sets which suggests that the disparity in education is likely to be due to a different classification method rather than inherent differences in educational achievement.

\footnotetext{
${ }^{4}$ Unlike the ATUS, which is a recall diary constructed for each respondent by a telephone interviewer who asks what the respondent was doing yesterday at 4:00 am, how long the activity lasted, who was there, and where the activity took place, continuing through the day for 24 hours, HETUS surveys are leave behind written diaries, which may be of higher quality but which are more costly to collect (Juster, 1985).
} 


\section{Table 1}

\section{Comparison of EPA and Spanish TUS}

\begin{tabular}{|c|c|c|c|c|c|c|}
\hline & \multicolumn{3}{|c|}{ EPA } & \multicolumn{3}{|c|}{ Time Use } \\
\hline & Both & Men & Women & Both & Men & Women \\
\hline Sex & 100 & 48.56 & 5.14 & 100 & 48.66 & 51.34 \\
\hline \multicolumn{7}{|l|}{ Age Groups } \\
\hline from 16 to 19 & 5.43 & 5.73 & 5.14 & 5.55 & 5.68 & 5.42 \\
\hline from 20 to 24 & 8.43 & 8.86 & 8.02 & 8.46 & 8.91 & 8.03 \\
\hline from 25 to 29 & 10.08 & 10.58 & 9.62 & 10.58 & 11.12 & 10.08 \\
\hline from 30 to 34 & 10.13 & 10.63 & 9.66 & 9.75 & 10.26 & 9.27 \\
\hline from 35 to 39 & 9.75 & 10.15 & 9.37 & 9.94 & 10.23 & 9.66 \\
\hline from 40 to 44 & 8.94 & 9.22 & 8.68 & 8.95 & 9,18 & 8.74 \\
\hline from 45 to 49 & 7.85 & 8.04 & 7.67 & 7.95 & 8.23 & 7.70 \\
\hline from 50 to 54 & 7.09 & 7.22 & 6.97 & 7.13 & 7.20 & 7.07 \\
\hline from 55 to 59 & 6.65 & 6.68 & 6.61 & 6.54 & 6.62 & 6.46 \\
\hline from 60 to 64 & 5.56 & 5.49 & 5.63 & 5.59 & 5.43 & 5.74 \\
\hline from 65 to 69 & 5.86 & 5.44 & 6.25 & 6.43 & 6.09 & 6.76 \\
\hline more than 70 & 14.22 & 11.95 & 16.37 & 13.12 & 11.05 & 15.07 \\
\hline \multicolumn{7}{|l|}{ Marital Status } \\
\hline Single & 31.05 & 35.19 & 27.15 & 30.27 & 33.76 & 26.96 \\
\hline Married & 58.61 & 60.32 & 57.00 & 59.55 & 61.39 & 57.80 \\
\hline Widow & 7.58 & 2.54 & 12.33 & 7.28 & 2.54 & 11.77 \\
\hline Divorced & 2.76 & 1.96 & 3.52 & 2.91 & 2.32 & 3.47 \\
\hline \multicolumn{7}{|l|}{ Education Level } \\
\hline No Education & 2.94 & 1.88 & 3.93 & 2.69 & 1.61 & 3.72 \\
\hline Primary Education & 35.61 & 33.31 & 37.79 & 28.61 & 26.53 & 30.57 \\
\hline Secondary Education ( $1^{\text {st }}$. stage $)$ & 25.04 & 27.10 & 23.09 & 30.37 & 31.56 & 29.25 \\
\hline Secondary Education (2nd. stage) & 16.86 & 17.25 & 16.50 & 17.04 & 17.95 & 16.17 \\
\hline Secondary Education (2nd. stage) plus professional training & 0.11 & 0.12 & 0.10 & 6.53 & 7.51 & 5.61 \\
\hline College & 19.19 & 20.01 & 18.43 & 14.29 & 14.18 & 14.41 \\
\hline $\mathrm{PhD}$ & 0.24 & 0.32 & 0.17 & 0.46 & 0.65 & 0.27 \\
\hline \multicolumn{7}{|l|}{ Employment Status } \\
\hline Labor Force Participation & 54.87 & 67.28 & 43.15 & 56.19 & 68.53 & 44.49 \\
\hline Unemployment & 11.12 & 7.95 & 15.79 & 10.43 & 7.48 & 14.73 \\
\hline
\end{tabular}

Note: values are in percentage terms.

\subsection{Sample and Descriptive Statistics}

The survey contains information on 60,493 respondents, of which $22.68 \%$ are children under 10 years old, and 20,603 households. For the empirical analysis in Section 4 we restrict the sample to those individuals between 20 and 65 who are married (8,876 couples). We restrict our analysis to those households where both spouses report positive earnings $\left(3,504\right.$ households). ${ }^{5}$ Including one-earner couples is problematic because the processes governing household decisions are understandably different in the two samples. This suggests that we should not combine one and two-earner households in the same regressions. More importantly we can offer no useful exclusion restrictions to impute missing earnings for those women out of the labor force, since everything that might be used to impute wages already appears in our time use regressions. Households where both spouses work fulltime, (3,314 households) have been considered. ${ }^{6}$ Finally, in order to get a clear representation of time use, the sample has been

\footnotetext{
${ }^{5}$ This is a 39 percent of the sample, which is consistent with the Spanish Employment Survey both partners work in 34 percent of households.

${ }^{6}$ Results are robust to including all two earner couples, given that part time work is not very common in Spain (upon request).
} 
restricted to those households where both spouses report a usual day as in Bonke (Bonke et al., 2005). ${ }^{7}$ All these restrictions leave the sample in 2,532 households. In those regressions where a form of childcare is the dependent variable we restrict the sample to those households with a child under 10 present, a total of 976 households. For the sake of consistency we present results only for those households for which we have information on all the variables for both spouses. This leaves us with 2,008 households for all the sample, and 736 households for the sample with children under 10.

Table 2 presents some summary statistics of the relevant socioeconomic variables used in the empirical analysis for the total sample and the sample of parents with children under 10 . The average age difference between spouses is two years, with men being 42 years old and women 40 years old on average. The average number of children living in the household is around 1.37 , which is very similar to the Spanish total fertility rate. ${ }^{8}$ About $40 \%$ of the households in our sample have children between 5 and 14 years old and about 25\% of households report having children less or equal than four years of age (this is almost $50 \%$ of the sample when only households with children are considered). Following De la Fuente and Jimeno (2005) we translate the ten educational categories provided in the survey into a variable that measures years of completed education. ${ }^{9}$ Although education is distributed almost evenly between men and women, with women slightly more educated, men tend to work about five hours more than women per week. The Spanish Time Use data does not contain information on hourly wages, but rather net monthly earnings. Net monthly earnings, as well as family income, are reported as a scale rather than as a continuous variable. We see that almost $60 \%$ of women have net monthly earnings under 1000 euros, whereas the distribution IS more disperse for men. Although women are slightly more educated than men only $4.5 \%$ of women versus $10 \%$ of men report net monthly earnings above 2000 euros. Household income measures total household income per month. It includes labor as well as non-labor income such as dividends or transfers. We have divided it into three categories: below 1500 euros, between 1500 and 3000 and higher than 3000 euros. Thus, the majority of households (about 60\%) fall in the intermediate category, with about 20\% falling in the other two categories, as observed.

\footnotetext{
${ }^{7}$ Individuals report the day as not being usual if it is not a usual day or work or study, meaning that they are either on holiday, on sick leave or not at work for some other reason. Results are robust to including these households (upon request).

${ }^{8}$ Although we only have information on children living in the household, the fact that children leave the parental home at a late age in Spain makes this variable a closer approximation to the actual number of children. Furthermore, the variable of interest for our analysis is the presence of children in the household, rather than the total number of children.

${ }^{9}$ Five years of education if the respondent reports primary studies or lower, eight years of education if the respondent reports a EGB degree, ten years of education if the respondent reports a FPI degree, twelve years of education if the respondent reports a BUP degree, 13 years of education if the respondent reports a FPII degree, 15 years of education if the respondent reports a Diplomatum or a 3 year university degree and 17 years of education if the respondent reports a Licenciatura or a 5 year university degree.
} 


\section{Table 2}

Summary statistics. Socioeconomic Variables

\begin{tabular}{|c|c|c|c|c|}
\hline \multirow[b]{2}{*}{ Demographic and Economic Variables } & \multicolumn{2}{|c|}{ All sample } & \multicolumn{2}{|c|}{ Sample of parents $<10$} \\
\hline & Husband & Wife & Husband & Wife \\
\hline Age & $\begin{array}{l}41.88 \\
(8.85)\end{array}$ & $\begin{array}{l}39.68 \\
(8.39)\end{array}$ & $\begin{array}{l}38.04 \\
(5.63)\end{array}$ & $\begin{array}{l}36.03 \\
(4.98)\end{array}$ \\
\hline Completed years of study & $\begin{array}{l}10.69 \\
(3.78)\end{array}$ & $\begin{array}{l}11.07 \\
(3.86)\end{array}$ & $\begin{array}{l}11.41 \\
(3.78)\end{array}$ & $\begin{array}{l}11.91 \\
(3.77)\end{array}$ \\
\hline Usual weekly hours of work & $\begin{array}{l}39.80 \\
(2.17)\end{array}$ & $\begin{array}{l}37.40 \\
(2.83)\end{array}$ & $\begin{array}{l}39.63 \\
(2.05)\end{array}$ & $\begin{array}{l}37.20 \\
(2.68)\end{array}$ \\
\hline Earnings less than $500 €$ & $2.97 \%$ & $16.63 \%$ & $2.73 \%$ & $14.61 \%$ \\
\hline Earnings between 500 and $999.99 €$ & $29.60 \%$ & $43.35 \%$ & $27.99 \%$ & $44.41 \%$ \\
\hline Earnings between 1000 and $1499.99 €$ & $42.64 \%$ & $25.89 \%$ & $44.36 \%$ & $25.45 \%$ \\
\hline Earnings between 1500 and $1999.99 €$ & $14.67 \%$ & $9.56 \%$ & $15.10 \%$ & $11.04 \%$ \\
\hline Earnings between 2000 and $2499.99 €$ & $5.42 \%$ & $3.12 \%$ & $4.38 \%$ & $2.65 \%$ \\
\hline Earnings between 2500 and $2999.99 €$ & $1.97 \%$ & $0.58 \%$ & $2.09 \%$ & $0.95 \%$ \\
\hline Earnings above $3000 €$ & $2.71 \%$ & $0.87 \%$ & $3.36 \%$ & $0.88 \%$ \\
\hline Household income under $1500 €$ & \multicolumn{2}{|c|}{$17.28 \%$} & \multicolumn{2}{|c|}{$19.00 \%$} \\
\hline Household income between 1500 and $3000 €$ & \multicolumn{2}{|c|}{$60.25 \%$} & \multicolumn{2}{|c|}{$60.79 \%$} \\
\hline Household income above $3000 €$ & \multicolumn{2}{|c|}{$22.47 \%$} & \multicolumn{2}{|c|}{0.20} \\
\hline No. of children & \multicolumn{2}{|c|}{$\begin{array}{r}1.37 \\
(0.97)\end{array}$} & \multicolumn{2}{|c|}{$\begin{array}{r}1.75 \\
(0.75)\end{array}$} \\
\hline No. of children $0-2$ & \multicolumn{2}{|c|}{$98.70 \%$} & \multicolumn{2}{|c|}{$23.82 \%$} \\
\hline No. of children 2-4 & \multirow{2}{*}{\multicolumn{2}{|c|}{$14.45 \%$}} & \multicolumn{2}{|c|}{$38.79 \%$} \\
\hline No. of children 5-14 & $38.98 \%$ & & \multicolumn{2}{|c|}{$67.57 \%$} \\
\hline No. of children + 15 (men) & \multicolumn{2}{|c|}{$24.38 \%$} & \multicolumn{2}{|c|}{$6.12 \%$} \\
\hline No. of children +15 (women) & \multicolumn{2}{|c|}{$24.21 \%$} & \multicolumn{2}{|c|}{$6.36 \%$} \\
\hline Household members & \multirow{2}{*}{\multicolumn{2}{|c|}{$\begin{array}{r}3.47 \\
(1.01) \\
\end{array}$}} & \multirow{2}{*}{\multicolumn{2}{|c|}{$\begin{array}{r}3.81 \\
(0.82) \\
\end{array}$}} \\
\hline & & & & \\
\hline Observations & \multicolumn{2}{|c|}{2,008} & \multicolumn{2}{|c|}{736} \\
\hline
\end{tabular}

Table 3 shows the time devoted to different housework activities. Our housework variable is reported in daily minutes and includes time devoted to cooking, cleaning, mending and maintenance of clothes, gardening and pets, household maintenance and repairs, shopping, and household management. We have also included any travel time needed to undertake any of these activities (for example, we record as shopping any time spent driving to the supermarket). Appendix A presents a full description of activities in each category, which follows the HETUS classification. Table 3 depicts a clear pattern of specialization within the household. The majority of women (99.15\%) undertake some housework activity vs. $77.63 \%$ of men. Women spend 215 minutes per day on housework whereas men spend 87 minutes. Thus, women spend almost three times more time in household chores than men. Specialization within the household is not only apparent with respect to total time, but also with respect to the type of activity. Consistent with other studies, women concentrate on routine and more time intensive housework, such as cooking and cleaning, whereas men are more active in sporadic and less time intensive tasks such as gardening, maintenance and repairs (Hersch and Stratton, 2000). 


\section{Table 3}

Daily minutes devoted to housework (all sample)

\begin{tabular}{|c|c|c|c|c|c|c|}
\hline \multirow[b]{2}{*}{ Housework time (minutes per day) } & \multicolumn{3}{|c|}{ Husbands } & \multicolumn{3}{|c|}{ Wives } \\
\hline & $\%$ & $\begin{array}{c}\text { Mean } \\
\text { (fraction wh } \\
\text { report } \\
\text { time }>0 \text { ) }\end{array}$ & $\begin{array}{c}\text { Mean } \\
\text { (whole } \\
\text { sample) }\end{array}$ & $\%$ & $\begin{array}{c}\text { Mean } \\
\text { (fraction who } \\
\text { report } \\
\text { time }>0 \text { ) }\end{array}$ & $\begin{array}{c}\text { Mean } \\
\text { (whole } \\
\text { sample) }\end{array}$ \\
\hline Total Housework & $77.63 \%$ & 111.72 & 86.73 & $99.15 \%$ & 216.77 & 214.93 \\
\hline Cooking & $61.57 \%$ & 46.50 & 28.63 & $94.37 \%$ & 94.43 & 89.11 \\
\hline Cleaning & $37.16 \%$ & 49.68 & 18.46 & $82.99 \%$ & 72.19 & 59.91 \\
\hline Laundry & $4.79 \%$ & 33.67 & 1.61 & $46.47 \%$ & 52.79 & 24.53 \\
\hline Gardening and Pets & $11.77 \%$ & 81.33 & 9.57 & $7.84 \%$ & 48.52 & 3.80 \\
\hline Maintenance and Repairs & $7.29 \%$ & 67.23 & 4.90 & $2.30 \%$ & 58.33 & 1.34 \\
\hline Shopping & $29.88 \%$ & 76.48 & 22.85 & $49.83 \%$ & 71.93 & 35.84 \\
\hline Household Management & $1.90 \%$ & 36.31 & 0.69 & $0.95 \%$ & 40.96 & 0.39 \\
\hline Observations & & 2,008 & & & 2,008 & \\
\hline
\end{tabular}

Table 4 reports daily minutes of housework and different measures of childcare time for the sub sample of households where a child under 10 years of age is present. We first define childcare 1 as all childcare reported as a primary activity. The variable childcare 1 measures time devoted to childcare activities during the designated day (dressing them up, helping them to eat, playing with them, taking them to school, etc.) as long as it is reported as a primary activity. We then construct childcare 2, which includes childcare reported as both primary and secondary activity. ${ }^{10}$ The latter refers to childcare mentioned in response to the query "Where you doing anything else?" (e.g., cooking dinner but also helping a child with homework). According to either measure women tend to spend more time in childcare activities than men, although the difference between genders are smaller than in the case of housework. On average women spend between 129 and 143 minutes on childcare 1 and childcare 2 respectively, whereas men devote 72 and 82 minutes per day respectively. Following Bianchi (2000) a third definition of childcare (childcare 3) uses information on whether a 10-year old child or younger was present while doing the main diary activity. This variable adds to childcare 2 any other time that the respondent spends with children and that has not been recorded as childcare in either the primary or the secondary activity (in order not to doublecount). Childcare 3 is closer to what has been called in the literature passive care, which is less likely to be categorized as leisure (Folbre et al., 2004). Table B1 in Appendix B shows what types of activities men and women do when a child less than 10 years old is present. Consistent with other time use surveys the type of activities women do when a child is present are housework, personal care and travel, whereas men tend to watch TV, do sports or socialize when a child is present. The absolute difference between wives and husbands increases to 100 minutes once this definition of childcare is introduced. Women spend 365 minutes with children under 10 whereas men spend 252 minutes on average.

\footnotetext{
10 The literature has found that in certain time use surveys childcare reported as primary activity significantly underreports total childcare time (Bianchi et al., 2006) and (Folbre et al., 2004). This however does not seem to be a crucial problem in the STUS, likely because the response rate for secondary activities is relatively low in the STUS compared to other time use surveys.
} 


\section{Table 4}

Daily minutes devoted to housework and childcare (sample of parents)

\begin{tabular}{|c|c|c|c|c|c|c|}
\hline \multirow[b]{2}{*}{ Housework time (minutes per day) } & \multicolumn{3}{|c|}{ Husbands } & \multicolumn{3}{|c|}{ Wives } \\
\hline & $\%$ & $\begin{array}{c}\text { Mean } \\
\text { (fraction } \\
\text { who report } \\
\text { time>0) }\end{array}$ & $\begin{array}{c}\text { Mean } \\
\text { (whole } \\
\text { sample) }\end{array}$ & $\%$ & $\begin{array}{c}\text { Mean } \\
\text { (fraction } \\
\text { who report } \\
\text { time>0) }\end{array}$ & $\begin{array}{c}\text { Mean } \\
\text { (whole } \\
\text { sample) }\end{array}$ \\
\hline $\begin{array}{l}\text { Total Housework } \\
\text { Cooking } \\
\text { Cleaning } \\
\text { Laundry } \\
\text { Gardening and Pets } \\
\text { Maintenance and Repairs } \\
\text { Shopping } \\
\text { Household Management }\end{array}$ & $\begin{array}{r}80.48 \% \\
67.68 \% \\
37.06 \% \\
6.37 \% \\
7.99 \% \\
6.67 \% \\
29.76 \% \\
1.84 \%\end{array}$ & $\begin{array}{r}105.10 \\
46.67 \\
53.65 \\
25.25 \\
69.74 \\
63.48 \\
70.57 \\
37.64\end{array}$ & $\begin{array}{r}84.58 \\
31.59 \\
19.88 \\
1.61 \\
5.57 \\
4.23 \\
21.00 \\
0.69\end{array}$ & $\begin{array}{r}98.86 \% \\
93.82 \% \\
81.85 \% \\
47.84 \% \\
5.25 \% \\
2.77 \% \\
45.97 \% \\
0.99 \%\end{array}$ & $\begin{array}{r}204.82 \\
90.44 \\
70.83 \\
50.42 \\
48.90 \\
37.41 \\
68.87 \\
29.21\end{array}$ & $\begin{array}{r}202.48 \\
84.85 \\
57.98 \\
24.12 \\
2.57 \\
1.04 \\
31.66 \\
0.29\end{array}$ \\
\hline \multicolumn{7}{|l|}{ Childcare } \\
\hline $\begin{array}{l}\text { Childcare } 1 \\
\text { Childcare } 2 \\
\text { Childcare } 3\end{array}$ & $\begin{array}{l}71.70 \% \\
73.14 \% \\
91.97 \%\end{array}$ & $\begin{array}{l}100.71 \\
112.05 \\
274.00\end{array}$ & $\begin{array}{r}72.21 \\
81.95 \\
252.00\end{array}$ & $\begin{array}{l}90.04 \% \\
91.11 \% \\
97.40 \%\end{array}$ & $\begin{array}{l}142.29 \\
156.76 \\
374.27\end{array}$ & $\begin{array}{l}128.12 \\
142.82 \\
364.54\end{array}$ \\
\hline Observations & & 736 & & & 736 & \\
\hline
\end{tabular}

Table 5 presents some indicators of household technology as well as of incidence of housework outsourcing. We can also see that almost all households have a microwave, a washing machine and a fridge. However, only about half have a dishwasher and about 25\% have a dryer or an independent freezer. The commonly outsourced household activities are cooking and cleaning, with a percentage of $7 \%$ and $19 \%$ respectively. ${ }^{11}$ Other activities that are outsourced are shopping and clothes repair, with about 4\% of households outsourcing these services. (percentages are a little bit higher for households with children under 10). Of all households 20\% report having a housekeeper, this percentage being 25\% among households with children under 10. About 40\% of households with children under 10 report some sort of childcare outsourcing. In turn, household outsourcing levels in those activities where women spend the majority of time (apart from childcare) are relatively low, which stresses the importance of substitution of time among household members rather than between the household and the market.

\footnotetext{
11 The question is whether the person being interviewed received any outside help in the last four weeks, where outside help is defined as help from a person, and not from a company or the public administration. This might explain low reported outsourcing levels for some activities such as repairs or maintenance.
} 


\section{Table 5}

Household technology and outsourcing indicators

\begin{tabular}{|c|c|c|}
\hline & All sample & $\begin{array}{l}\text { Parents of } \\
\text { children }<10\end{array}$ \\
\hline \multicolumn{3}{|l|}{ "Household Technology } \\
\hline $\begin{array}{l}\text { Microwave } \\
\text { Dishwasher } \\
\text { Washing machine } \\
\text { Dryer } \\
\text { Fridge } \\
\text { Independent freezer }\end{array}$ & $\begin{array}{l}84.57 \% \\
53.62 \% \\
99.36 \% \\
26.94 \% \\
99.32 \% \\
26.95 \%\end{array}$ & $\begin{array}{l}86.08 \% \\
58.14 \% \\
99.82 \% \\
32.25 \% \\
99.71 \% \\
24.67 \%\end{array}$ \\
\hline \multicolumn{3}{|l|}{ Outside Help } \\
\hline $\begin{array}{l}\text { Meal preparation } \\
\text { Household Maintenance } \\
\text { Clothes } \\
\text { Gardening and pets } \\
\text { Repairs } \\
\text { Household shopping } \\
\text { Household management } \\
\text { Childcare } \\
\text { Paid housekeeper }\end{array}$ & $\begin{array}{r}6.59 \% \\
18.86 \% \\
4.32 \% \\
0.99 \% \\
1.74 \% \\
2.67 \% \\
1.35 \% \\
22.54 \% \\
20.22 \%\end{array}$ & $\begin{array}{r}9.82 \% \\
23.77 \% \\
5.87 \% \\
1.12 \% \\
1.89 \% \\
3.43 \% \\
1.58 \% \\
56.24 \% \\
29.30 \%\end{array}$ \\
\hline Observations & 2,008 & 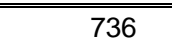 \\
\hline
\end{tabular}

\section{Empirical Specification}

The goal of this paper is to estimate to what extent household specialization is driven by the spouses' relative earnings, i.e. by the specialization or the bargaining effect, or by social norms. To do so we use the following specification:

$$
h_{i \kappa}=w_{i 0 \kappa} \beta_{0 \kappa}+w_{i 1 \kappa} \beta_{1 \kappa}+X_{i \kappa} \gamma_{\kappa}+\varepsilon_{i \kappa}
$$

The dependent variable is the degree of specialization measured by the wife's share of house-work $h_{i \kappa}$ in any given household $i$ and household activity $\kappa$, and is defined as $h_{i k}=\frac{H_{i, f}}{H_{i, f}+H_{i, m}}$, for $H_{i, f}$ and $H_{i, m}$ the wife and the husband's housework time in activity $\kappa$. In the analysis in Section 4 we report weighted Tobit estimators and perform the analysis separately for housework and childcare. A Tobit specification is preferable given that there are a lot of men that report zero time in housework and thus this ratio is truncated at value $1 .^{12}$

The coefficients of interest are $\beta_{0}$ and $\beta_{l}$, where $w_{i 0}$ is an indicator variable that takes value 1 if spouses have the same monthly earnings and 0 otherwise and $w_{i 1}$ is an indicator variable that takes value 1 if the wife's earnings are greater than the husband's and 0 otherwise. Thus the comparison category is the case when a husband earns more than his wife. The STUS does not contain information on hourly wages, so we use net monthly earnings instead. Using earnings in the right hand side is problematic since hours of work are jointly determined with hours of

\footnotetext{
${ }^{12}$ Weighted OLS did not significantly change the results (available upon request).
} 
housework. We account for this potential bias by reducing the sample to those couples where both partners work full-time. ${ }^{13}$

Given any household activity $\kappa$, traditional models of the household and social norm theories would predict that $\beta_{0 k}$ and $\beta_{1 k}$, are both negative, i.e. the relative share of time devoted to activity $\kappa$ decreases as relative earnings increase. However, social norm theories predict that a woman's share of time in activity $\kappa$ fails to decrease or even increases once a certain level of female relative earnings has been achieved, i.e. $\left|\beta_{0 \kappa}\right| \geq\left|\beta_{1 \kappa}\right|$. In other words, whereas traditional theories of the household predict that a woman's relative share of housework decreases with her relative earnings so that $\left|\beta_{0 \kappa}\right| \leq\left|\beta_{1 \kappa}\right|$, social norm theories predict that higher relative earning women perform an equal or higher share of household chores than lower relative earning women. Section 4 tests this prediction for the case of housework and childcare time.

Because we are interested in the presence of social norms, net of the household optimization process (i.e. net of specialization and bargaining effects), the variables in $X_{i}$ include the usual household and individual variables to account for bargaining and specialization factors within the household such as income and completed years of education. We present several specifications of equation (1). We also control for individual and household heterogeneity in the production of household services and preferences. We include household composition (number of people in the household and the presence of children in different age ranges), the number of rooms in the house, the presence of a microwave and other devices that might affect spouses' productivity in household goods and whether the household receives any external help (paid or unpaid) in the provision of household services. In some of our specifications we also include regional dummies. We also control for cohort specific heterogeneity by including spouses' ages. All the specifications include an indicator variable that takes value one if the interview took place during a week-day (Monday through Friday).

\section{Empirical Results}

This section estimates Equation 1 to test the presence of social norms on the household division of labor for the case of housework and childcare.

\subsection{Social Norms and the Division of Housework}

Table 6 shows some preliminary but already surprising results with respect to how the time that both spouses devote to housework and paid work changes with respect to spouses' relative earnings. I.e. when a wife's relative earnings are higher, equal and lower than her husband's. It also shows the variation in household specialization, defined as the time the woman spends in any housework over the total amount of time that both spouses spend in that activity. Housework is defined as the sum of the time devoted to cooking, cleaning, mending and maintenance of clothes, gardening and pets, household maintenance and repairs, shopping, and household management and any travel time associated with these activities. First, similar to PSID evidence, even women contributing to more than 50\% of the household income engage in more than 50\% of household production. On average, a woman's share of total housework time is .76 when she earns less than her husbands, .71 when she earns the same and .68 when she

\footnotetext{
${ }^{13}$ This is not a very strong restriction for the case of Spain where part time work is not widely extended. Results are robust to include all two earner couples (upon request).
} 
earns more. This figure is very similar to Akerlof and Kranton's figure from the PSID, where wives earning the same as their husbands still perform about $70 \%$ of the housework. This would be consistent with traditional models of the household if we assume that women have either higher productivity or higher tastes for housework than men. However, even under this assumption it would not necessarily follow why the rate at which a woman's relative share of housework decreases is lower as her relative earnings increase. In fact women devote less time to housework activities as her relative earnings increase: 229 minutes when they earn less, 204 when they earn the same and 189 when they earn more. However, men's housework time increases from 82 to 92 minutes as women's earnings increase but decrease again to 87 minutes when women earnings increase beyond men's earnings. Thus, as is found in longitudinal studies, man's housework time fails to increase at the same rate that woman's housework time decreases, which causes the specialization ratio to remain fairly constant. These findings already point to social norms that dictate the household division of labor. The results in Table 6 cannot be interpreted causally. The variation that we observe in Table 6 might to be due to either household or individual heterogeneity (for instance, women that earn more than their husbands might have higher standards of household production, i.e. higher taste for household produced goods, which might explain why they do relatively more housework than lower relative earning women). Table 7 presents conditional results to see if the relationship between household specialization and relative earnings observed in Table 6 still holds after household and individual observed heterogeneity is controlled for.

\section{Table 6}

Housework, paid labor and relative earnings

\begin{tabular}{|c|c|c|c|c|}
\hline & Husband & Wife & Ratio & Obs. \\
\hline Net monthly earnings & \multicolumn{4}{|c|}{ Daily minutes of housework } \\
\hline Wife earns less than husband & $\begin{array}{c}82.36 \\
(98.96)\end{array}$ & $\begin{array}{c}228.53 \\
(126.39)\end{array}$ & $\begin{array}{c}0.76 \\
(0.22)\end{array}$ & 1017 \\
\hline Wife earns the same as husband & $\begin{array}{c}92.30 \\
(101.85)\end{array}$ & $\begin{array}{c}204.33 \\
(124.39)\end{array}$ & $\begin{array}{l}0.71 \\
(0.25)\end{array}$ & 792 \\
\hline \multirow[t]{2}{*}{ Wife earns more than husband } & $\begin{array}{c}86.90 \\
(84.11)\end{array}$ & $\begin{array}{c}188.57 \\
(112.67)\end{array}$ & $\begin{array}{c}0.68 \\
(0.24)\end{array}$ & 199 \\
\hline & \multicolumn{4}{|c|}{ Daily minutes of paidwork } \\
\hline Wife earns less than husband & $\begin{array}{c}406.97 \\
(245.89)\end{array}$ & $\begin{array}{c}310.42 \\
(208.94)\end{array}$ & $\begin{array}{c}0.43 \\
(0.22)\end{array}$ & 1017 \\
\hline Wife earns the same as husband & $\begin{array}{c}390.49 \\
(246.55)\end{array}$ & $\begin{array}{c}331.38 \\
(214.66)\end{array}$ & $\begin{array}{c}0.46 \\
(0.21)\end{array}$ & 792 \\
\hline Wife earns more than husband & $\begin{array}{c}406.47 \\
(221.55)\end{array}$ & $\begin{array}{c}334.33 \\
(196.55)\end{array}$ & $\begin{array}{c}0.45 \\
(0.18)\end{array}$ & 199 \\
\hline
\end{tabular}

Note: Standard deviation in parenthesis. 
The first column in Table 7 is, except for the fact that we are also controlling for whether it is a week-day or a weekend, the mirror image of the third column in Table 6, i.e. it shows the unconditional results of the variation in housework specialization and relative earnings. The rest of the columns in Table 7 present different specifications of Equation 1 to take into account several sources of household and individual heterogeneity. The main results do not change substantially across specifications. Table 7 shows that a wife that earns the same as her husband has a housework share of 5 percentage points lower than a wife that earns less than her husband. The magnitude of the decline is independent of the specification used. Similarly, Column 1 in Table 7 shows that a wife that earns more than her husband has a housework share of 10 percentage points lower than a wife that earns less than her husband. The size of the coefficient decreases to about 7.7 once household incomes and spouse's education are both controlled, but remains at 7.7 even after controlling for heterogeneity in household production and preferences. Although a few percentage points in the specialization ration might come across as a small variation, Table 6 shows that they might represent an important amount of a woman's time (up to three hours a week).

The results presented in Table 7 might seem consistent with competitive or bargaining theories of the household at first, but a closer look provides some support to the social norm theories presented here. First, higher earning women are not able to reduce their participation in housework activities at the same rate as lower earning women. Whereas women earning the same as their husbands reduce their housework share by 5 percentage points with respect to women earning less than their husbands, the additional decrease for women earning more than their husbands is only 3.5 percentage points (in most specifications). Second, although both $\beta_{0}$ and $\beta_{1}$ are negative and significantly different from each other, once we introduce the variables that control for spouses' age (from specification 3 through 6) we cannot reject the hypothesis that $\beta_{0}$ and $\beta_{1}$ are significantly different from each other. The last row of Table 7 shows that a Wald test for the null hypothesis that $\beta_{0}=\beta_{1}$ cannot be rejected at the $90 \%$ level. Therefore, the fact that a woman's share of housework time fails to decrease once a wife's relative earnings are higher than her husband's provides some evidence for the existence of social norms or constraints on the household allocation of housework time.

The rest of the coefficients exhibit the expected signs. The coefficient on family income is negative although not always significant, especially after controlling for the spouses' education attainment. This is likely so because household income might be capturing the effect of education, in fact those households with income greater than 3000 euros, a $22 \%$ of the sample, are also those households were both spouses have the highest education attainment. The role of education is as expected, the higher the wife's as well as the husband's level of education, the lower the participation of the wife on total housework. However, the coefficients, although significant, turn out to be quite small. Regarding age, wife's as well as husband's age seem to have a positive effect on the proportion of housework carried out by the wife. However, the size of the coefficient is very small and it is only significant in the case of the wives. Finally, whereas the number of members in the household and being a weekday increases the wife's share of housework, having a paid housekeeper seems to decrease the wife's share of housework but the coefficient is not significant. 


\section{Table 7}

The division of housework

\begin{tabular}{|c|c|c|c|c|c|c|}
\hline Wife's share of housework time & (1) & (2) & (3) & (4) & (5) & (6) \\
\hline wife earns same as husband & -0.05586 & -0.05977 & -0.05986 & $\begin{array}{l}-0.052 \\
(363)^{* * *}\end{array}$ & $\begin{array}{l}-0.051 \\
(360)^{* * *}\end{array}$ & $\begin{aligned}-0.050 \\
-39\end{aligned}$ \\
\hline wife earns more than husband & -0.10633 & -0.10156 & -0.09170 & -0.076 & -0.078 & -0.077 \\
\hline & $(4.64)^{\star \star *}$ & $(4.43)^{\star * \star}$ & $(4.06)^{\star \star *}$ & $(3.29)^{\star * *}$ & $(3.39)^{\star \star \star}$ & $(3.36)^{\star * *}$ \\
\hline household income between 1500 and $3000 \mathrm{E}$ & & $\begin{array}{l}-0.06158 \\
(3.32)^{\star * *}\end{array}$ & $\begin{array}{l}-0.07514 \\
(4.10)^{\star * *}\end{array}$ & $\begin{array}{c}-0.051 \\
(2.75)^{\star \star \star}\end{array}$ & $\begin{array}{c}-0.039 \\
(2.05)^{\star \star}\end{array}$ & $\begin{array}{r}-0.039 \\
(2.02)^{* *}\end{array}$ \\
\hline household income higher than $3000 \mathrm{E}$ & & -0.03025 & -0.07756 & -0.015 & 0.002 & -0.006 \\
\hline & & $(1.39)$ & $(3.50)^{\star \star \star}$ & $(0.59)$ & $(0.07)$ & $(0.25)$ \\
\hline wife's age & & & 0.00368 & 0.004 & 0.004 & 0.003 \\
\hline & & & $(1.75)^{\star}$ & $(1.70)^{*}$ & $(1.89)^{*}$ & $(1.66)^{\star}$ \\
\hline husband's age & & & 0.00349 & 0.002 & 0.002 & 0.001 \\
\hline & & & $(1.77)^{\star}$ & $(1.10)$ & $(0.81)$ & $(0.55)$ \\
\hline wife's years of education & & & & -0.006 & -0.006 & -0.005 \\
\hline & & & & $(2.63)^{\star * *}$ & $(2.55)^{\star *}$ & $(1.94)^{*}$ \\
\hline husband's years of education & & & & -0.007 & -0.007 & -0.007 \\
\hline & & & & $(2.93)^{\star \star \star}$ & $(3.01)^{\star \star \star}$ & $(2.91)^{\star \star \star}$ \\
\hline region dummies & & & & & yes & yes \\
\hline paid housekeeper & & & & & & -0.037 \\
\hline & & & & & & $(1.34)$ \\
\hline number of members in the household & & & & & & 0.038 \\
\hline & & & & & & $(5.29)^{\star * *}$ \\
\hline househald technology dummies & & & & & & yes \\
\hline housework outsourcing dummies & & & & & & yes \\
\hline week-day observation & 0.09751 & 0.09664 & 0.10181 & 0.105 & 0.107 & 0.111 \\
\hline & $(6.61)^{\star \star \star}$ & $(6.57)^{\star \star \star}$ & $(7.02)^{\star \star *}$ & $(7.28)^{\star \star *}$ & $(7.48)^{\star \star \star}$ & $(7.81)^{\star \star \star}$ \\
\hline constant & 0.73634 & 0.78176 & 0.50257 & 0.666 & 0.696 & 0.634 \\
\hline & $(52.57)^{\star * *}$ & $(37.60) * * *$ & $(13.15)^{\star * *}$ & $(14.02)^{\star * \star}$ & $3.72)^{\star * *}(1$ & $0.76)^{\star * *}$ \\
\hline Observations & 2,008 & 2,008 & 2,008 & 2,008 & 2,008 & 2,008 \\
\hline R-squared & 0.037 & 0.043 & 0.082 & 0.100 & 0.121 & 0.144 \\
\hline $\mathrm{p}>\mathrm{F}$ b0 $=\mathrm{b} 1$ & 0.03 & 0.08 & 0.17 & 0.30 & 0.25 & 0.28 \\
\hline
\end{tabular}

Tobit estimates (all sample)

Significance levels: * $10 \% ;{ }^{* *} 5 \% ;{ }^{* * *} 1 \%$

One factor that might be causing the observed flat pattern of household specialization as the wife's relative earnings increase might be the fact that our indicators for relative earnings might not be measuring the same variation in relative earnings. In fact, the average difference between a husband and a wife's earnings is of 764.99 euros if the wife earns less than her husband but goes down to -690.95 if the wife earns more than her husband. Therefore the size of the change from earning less than her husbands to earning the same as her husband is slightly bigger (although statistically significant) than the size of the change from earning the same to earning more than her husband. In order to account for this potential bias we construct a wider range of relative earnings indicators. Results, are robust to these specifications and earning more than a husband, although significantly different from 0 , does not imply any additional reduction in the wife's share of housework time with respect to a woman earning the same as her husband. ${ }^{14}$

\footnotetext{
14 These specifications have 5 indicator variables to measure spouses relative earnings rather than 3: A woman earns more than 500 euros less than her husband, a woman earns no more than 500 euros less than her husband, a woman earns the same than her husband, a woman earns no more than 500 euros more than her husband and a woman earns more than 500 euros more than her husband.
} 
One of the coefficients in Table 7 that is significant in all specification is the indicator variable of whether it is a weekday or a weekend day. Table 3 in Section 2 showed that most housework activities must be performed weekly, with $99 \%$ of women do some housework during the week. Also because there are no labor market obligations during the weekend, spare time is greater during the weekend than during week days. Thus, we would expect that spouses are able to make intertemporal substitutions of housework and postpone some housework time during week days, when the time constraint that households face is more likely to bind, to be done during the weekend. It could be argued that this substitution is particularly important for women whose earnings are higher than their husbands because these women might have more demanding jobs. Pooling both samples together, the sample of the week days and weekends, might then produce the artificial result of constant patterns of relative housework for all women independent of their relative earnings. In order to tackle this question we divide the sample and estimate Equation 1 over two separate subsamples: the subsample of couples who filled out the diary on a week-day and the subsample of couples who filled out the diary on a weekend-day.

The first 6 columns in Table 8 shows, that during the week the same conclusion as in Table 7 follows. During week days women earning more than their husbands seem to reduce the relative share of housework with respect to women that earn the same or less than their husbands ( $\beta_{1}=-0.8$ according to specification 6$)$. However, as in the pooled sample, we cannot reject the hypothesis that $\beta_{0}$ and $\beta_{1}$, are significantly different from each other. The last row of Table 8 shows that a Wald test for the null hypothesis that $\beta_{0}=\beta_{1}$ cannot be rejected at the 90\% level. Thus a woman's share of housework time during week days fails to decrease with relative earnings once a wife's relative earnings are equal to her husband's. On the other hand, during the weekend household specialization not only does not decrease with relative earnings, it actually increases. Although a woman that earns the same as her husband has a specialization ratio that is .07 percentage points lower than a woman that earns less than her husband, a woman that earns more than her husband only reduces her share by .01 more. Once we control for education and other household and individual observable heterogeneity the coefficient on the indicator variable is not significantly different from zero. This would suggest that higher relative earning women would actually increase their housework share during the weekend with respect to equal relative earning women, which would go in line with the doing-gender hypothesis. ${ }^{15}$

\footnotetext{
${ }^{15}$ One must be cautious when interpreting this result given that there are very few women with earnings higher than their husbands in our weekend sample.
} 


\section{Table 8}

The division of housework, week vs. weekend

\begin{tabular}{|c|c|c|c|c|c|c|c|c|c|c|c|c|}
\hline \multirow[t]{2}{*}{ Wife's share of housework time } & \multicolumn{6}{|c|}{ Week } & \multicolumn{6}{|c|}{ Week-end } \\
\hline & $(1)$ & (2) & C3) & $(4)$ & $(5)$ & (6) & (1) & (2) & C3) & (4) & (5) & (6) \\
\hline wife earns same as husband & $\begin{array}{c}-0.04511 \\
(2.57)^{* *}\end{array}$ & $\begin{array}{l}-0.04840 \\
(2.75)^{\star \star \star}\end{array}$ & $\begin{array}{l}-0.05001 \\
(2.87)^{\star \star \star}\end{array}$ & $\begin{array}{l}-0.042 \\
(2.41)^{\star \star}\end{array}$ & $\begin{array}{l}-0.041 \\
(2.33)^{\star \star}\end{array}$ & $\begin{array}{c}-0.039 \\
(2.27)^{\star \star}\end{array}$ & $\begin{array}{l}-0.07997 \\
(3.24)^{\star * *}\end{array}$ & $\begin{array}{l}-0.08465 \\
(3.45)^{\star \star \star}\end{array}$ & $\begin{array}{l}-0.08056 \\
(3.37)^{\star * \star}\end{array}$ & $\begin{array}{c}-0.071 \\
(2.94)^{\star * *}\end{array}$ & $\begin{array}{l}-0.070 \\
(2.95)^{\star \star \star}\end{array}$ & $\begin{array}{l}-0.073 \\
(3.03)^{* *}\end{array}$ \\
\hline wife earns more than husband & $\begin{array}{l}-0.11133 \\
(4.12)^{n+*}\end{array}$ & $\begin{array}{l}-0.10967 \\
(4.06)^{* * *}\end{array}$ & $\begin{array}{l}-0.09829 \\
(3.67)^{*+*+}\end{array}$ & $\begin{array}{l}-0.084 \\
(3.08)^{*}\end{array}$ & $\begin{array}{l}-0.082 \\
(2.99)^{* *}\end{array}$ & $\begin{array}{l}-0.078 \\
(2.88)^{* *}\end{array}$ & $\begin{array}{c}-0.08683 \\
(1.98)^{*+}\end{array}$ & $\begin{array}{c}-0.007306 \\
(1.67)^{*}\end{array}$ & $\begin{array}{c}-0.06992 \\
(1.64)\end{array}$ & $\begin{array}{c}-0.048 \\
(1.11)\end{array}$ & $\begin{array}{c}-0.042 \\
(0.97)\end{array}$ & $\begin{array}{c}-0.03989 \\
(0.92)\end{array}$ \\
\hline household income between 1500 and 3000 & & $\begin{array}{c}-0.04977 \\
(2.21)^{*+}\end{array}$ & $\begin{array}{l}-0.06223 \\
(2.77)^{2=1}\end{array}$ & $\begin{array}{c}-0.037 \\
(1.63)\end{array}$ & $\begin{array}{l}-0.026 \\
(1.13)\end{array}$ & $\begin{array}{l}-0.024 \\
(1.03)\end{array}$ & & $\begin{array}{c}-0.09031 \\
(2.79)^{*+1}\end{array}$ & $\begin{array}{c}-0.10589 \\
(3.34)^{-1}\end{array}$ & $\begin{array}{l}-0.085 \\
(2.65)^{* * *}\end{array}$ & $\begin{array}{l}-0.075 \\
(2.32)^{* *}\end{array}$ & $\begin{array}{l}-0.083 \\
(2.50)^{*}\end{array}$ \\
\hline household income higher than $3000 \mathrm{E}$ & & $\begin{array}{c}-0.01613 \\
(0.61)\end{array}$ & $\begin{array}{c}-0.06175 \\
(2.27)^{*+}\end{array}$ & $\begin{array}{l}0.005 \\
(0.18)\end{array}$ & $\begin{array}{l}0.019 \\
(0.63)\end{array}$ & $\begin{array}{l}0.006 \\
(0.18)\end{array}$ & & $\begin{array}{c}-0.06161 \\
(1.63)\end{array}$ & $\begin{array}{c}-0.11191 \\
(2.95)^{1+*}\end{array}$ & $\begin{array}{c}-0.057 \\
(1.38)\end{array}$ & $\begin{array}{c}-0.049 \\
(1.18)\end{array}$ & $\begin{array}{l}-0.051 \\
(1.19)\end{array}$ \\
\hline wife's age & & & $\begin{array}{c}0.00311 \\
(1.24)\end{array}$ & $\begin{array}{l}0.003 \\
(1.23)\end{array}$ & $\begin{array}{l}0.003 \\
(1.31)\end{array}$ & $\begin{array}{l}0.002 \\
(0.99)\end{array}$ & & & $\begin{array}{c}0.00515 \\
(1.33)\end{array}$ & $\begin{array}{l}0.005 \\
(1.24)\end{array}$ & $\begin{array}{l}0.005 \\
(1.37)\end{array}$ & $\begin{array}{l}0.005 \\
(1.21)\end{array}$ \\
\hline husband's age & & & $\begin{array}{c}0.00348 \\
(1.47)\end{array}$ & $\begin{array}{l}0.002 \\
(0.86)\end{array}$ & $\begin{array}{l}0.002 \\
(0.68)\end{array}$ & $\begin{array}{l}0.001 \\
(0.30)\end{array}$ & & & $\begin{array}{c}0.00335 \\
(0.92)\end{array}$ & $\begin{array}{l}0.002 \\
(0.66)\end{array}$ & $\begin{array}{l}0.002 \\
(0.66)\end{array}$ & $\begin{array}{l}0.003 \\
(0.78)\end{array}$ \\
\hline wife's years of education & & & & $\begin{array}{l}-0.006 \\
(1.95)^{*}\end{array}$ & $\begin{array}{l}-0.006 \\
(1.96)^{* *}\end{array}$ & $\begin{array}{l}-0.005 \\
(1.63)\end{array}$ & & & & $\begin{array}{l}-0.007 \\
(1.92)^{*}\end{array}$ & $\begin{array}{l}-0.006 \\
(1.71)^{*}\end{array}$ & $\begin{array}{l}-0.005 \\
(1.23)\end{array}$ \\
\hline husband's years of education & & & & $\begin{array}{l}-0.008 \\
(279)^{*+*}\end{array}$ & $\begin{array}{l}-0.009 \\
3.00)^{\prime}\end{array}$ & $\begin{array}{l}-0.008 \\
0\end{array}$ & & & & -0.004 & -0.002 & -0.00182 \\
\hline region dummies & & & & & $\begin{array}{r}(.00) \\
\text { yes }\end{array}$ & $\begin{array}{r}(2.72) \\
\text { yes }\end{array}$ & & & & & $\begin{array}{c}(0.66) \\
\text { yes }\end{array}$ & $\begin{array}{l}\text { (0.48) } \\
\text { yes }\end{array}$ \\
\hline paid housekeeper & & & & & & $\begin{array}{l}-0.041 \\
(1.22)\end{array}$ & & & & & & $\begin{array}{l}-0.039 \\
(0.81)\end{array}$ \\
\hline number of members in the household & & & & & & 0.050 & & & & & & $\begin{array}{l}0.015 \\
(125)\end{array}$ \\
\hline household technology dummies & & & & & & $\begin{array}{c}(5.5)^{n-n} \\
\text { yes }\end{array}$ & & & & & & $\begin{array}{l}(1.25) \\
\text { yes }\end{array}$ \\
\hline housework outsourcing dummies & & & & & & yes & & & & & & yes \\
\hline constant & $\begin{array}{c}0.83158 \\
(70.73)^{\star \star *}\end{array}$ & $\begin{array}{c}0.86599 \\
(39.34)^{\star \star \star}\end{array}$ & $\begin{array}{c}0.61399 \\
(13.90)^{\star \star \star}\end{array}$ & $\begin{array}{c}0.791 \\
(13.84)^{\star \star \star}\end{array}$ & $\begin{array}{c}0.812 \\
(13.23)^{\star \star \star}\end{array}$ & $\begin{array}{c}0.755 \\
(10.45)^{\star \star *}\end{array}$ & $\begin{array}{c}0.74256 \\
(45.36)^{\star \star \star}\end{array}$ & $\begin{array}{c}0.81193 \\
(25.98)^{* \star *}\end{array}$ & $\begin{array}{l}0.47945 \\
(7.47)^{\star \star \star}\end{array}$ & $\begin{array}{c}0.624 \\
(7.93)^{\star \star \star}\end{array}$ & $\begin{array}{c}0.661 \\
(8.02)^{\star \star \star}\end{array}$ & $\begin{array}{c}0.615 \\
(6.47)^{\star * \star}\end{array}$ \\
\hline Observations & 1420 & 1420 & 1420 & 1420 & 1420 & 1420 & 588 & 588 & 588 & 588 & 588 & 588 \\
\hline R squared & 0.014 & 0.018 & 0.049 & 0.067 & 0.092 & 0.127 & 0.025 & 0.042 & 0.114 & 0.134 & 0.198 & 0.215 \\
\hline $\mathrm{p}>\mathrm{F} \mathrm{b} 0=\mathrm{b} 1$ & 0.02 & 0.03 & 0.08 & 0.13 & 0.14 & 0.16 & 0.88 & 0.80 & 0.81 & 0.60 & 0.52 & 0.46 \\
\hline
\end{tabular}

The results presented in this section follow through when the dependent variable is specialization in female-specific household activities (such as cleaning, cooking, ironing, shopping and traveling). These households activities are done routinely and are more likely to be considered as housework than male-specific activities such as gardening, which is done sporadically and might have a higher consumption component. Comparison of male and female specific activities is however not possible due to the drop in sample sizes for those activities commonly performed by men. ${ }^{16}$

\subsection{Social Norms and the Allocation of Childcare Time}

Our analysis has been focused now on childcare. Conceptualizing childcare as housework is difficult. Unlike housework, time devoted to childcare might produce direct utility (even at the margin), being conceptually closer to leisure. In fact Table 9 shows that women devote more time to Childcare 1 and Childcare 2 as female relative earnings increase, which suggests that the conceptualization of childcare as housework might be more subtle than it might appear at first. If childcare time is closer to be conceptualized as leisure than housework it would not be surprising that as a woman's relative earnings increase she is able to either negotiate more of this good (in line with bargaining theories). This story however is not quite clear for men, whose childcare increases as well over the entire relative earnings distribution. There might also be substitution and income effects associated to childcare, so that as female relative earnings go up total income in the household goes up and both spouses could in principle enjoy more leisure (a normal good) and in this particular case, more childcare. The picture for Childcare 3 is slightly different because it displays a U-shape pattern, e.g. it decreases as a woman goes from

${ }^{16}$ Results available upon request. 
earning less to earning the same as her husband, but increases again as she earns more than him. This pattern might be explained by the fact that the nature of childcare that the woman performs changes with her relative earnings.

Based on the primary activity that the adult is doing in the presence of a child, diary data allows us to make some distinction between childcare that might be conceptualized as housework because it can be easily outsourced or no direct utility is derived (for example, picking children up from school) and which childcare entails leisure (for example, playing with a child). We construct two variables childcare-routine and childcare-leisure. The variable childcare-leisure is constructed as the sum of any time devoted leisure activities (including playing with children) reported as a primary activities in the performed in the company of a child under 10 years old. We construct childcare-routine as the sum of any time devoted to childcare reported as primary or secondary activity (except playing with a child) and any other primary activity that is considered to be non-leisure activities (cleaning, shopping, eating, etc.) as long as they are performed in the company of a child under 10 years old. ${ }^{17}$ Obviously this method has many drawbacks. Leisure activities perform with a child might not be as pleasant as leisure activities perform with adults. The data can inform on this to some extent.

Table 9 shows how childcare changes with relative earnings. We observe that in the case of the three broad definitions of childcare (Childeare 1 through Childcare 3) the ratio is fairly constant, but the variations of woman and man's absolute childcare times make it evident that one cannot infer whether childcare is leisure or housework, as absolute childcare time increases with relative earnings for both spouses. However, when we divide Childcare 3 into childcare-routine and childcare-leisure we observe that the absolute time devoted to childcare-routine decreases for women and increases for men as female relative earnings go up. In the case of childcare-leisure it increases for both men and women as relative earnings go up. These two findings suggest that our definition of childcare routine is likely to be capturing childcare activities that are conceptually closer to housework than leisure. Again, as in the case of Table 6, the ratios presented on Table 9 refer to unconditional variations of childcare as female relative earnings increase might be subject to household or individual heterogeneity. For instance, women that earn more than their husbands might have higher standards of childcare, maybe because of their higher education attainment. This might explain why they failed to decrease the proportion of childcare they do in relation to lower relative earning women.

\footnotetext{
${ }^{17}$ Table A.3 in Appendix C shows which primary activities we are defining as leisure and which we are defining as non leisure activities. We have constructed different definitions of childcare leisure and childcare routine, including or excluding secondary childcare and changing the classification. Results are robust to these different specifications and are available upon request.
} 


\section{Table 9}

Childcare and relative earnings

\begin{tabular}{|c|c|c|c|c|}
\hline & Husband & Wife & Ratio & Obs. \\
\hline & \multicolumn{4}{|c|}{ Daily minutes of childcare 1} \\
\hline Wife earns less than husband & $\begin{array}{c}66.65 \\
(77.51)\end{array}$ & $\begin{array}{c}124.80 \\
(100.77)\end{array}$ & $\begin{array}{c}0.68 \\
(0.27)\end{array}$ & 356 \\
\hline Wife earns the same as husband & $\begin{array}{c}75.15 \\
(81.92)\end{array}$ & $\begin{array}{c}130.42 \\
(109.41)\end{array}$ & $\begin{array}{c}0.66 \\
(0.27)\end{array}$ & 308 \\
\hline Wife earns more than husband & $\begin{array}{c}88.67 \\
(95.36)\end{array}$ & $\begin{array}{c}135.03 \\
(99.30) \\
\text { Daily minut }\end{array}$ & $\begin{array}{c}0.67 \\
(0.26) \\
\text { hildcare }\end{array}$ & 72 \\
\hline Wife earns less than husband & $\begin{array}{c}75.10 \\
(88.07)\end{array}$ & $\begin{array}{c}138.62 \\
(109.83)\end{array}$ & $\begin{array}{c}0.68 \\
(0.27)\end{array}$ & 356 \\
\hline Wife earns the same as husband & $\begin{array}{c}86.91 \\
(98.85)\end{array}$ & $\begin{array}{c}143.59 \\
(122.52)\end{array}$ & $\begin{array}{c}0.65 \\
(0.28)\end{array}$ & 308 \\
\hline Wife earns more than husband & $\begin{array}{c}95.91 \\
(100.59)\end{array}$ & $\begin{array}{c}161.66 \\
(126.20)\end{array}$ & $\begin{array}{c}0.69 \\
(0.25)\end{array}$ & 72 \\
\hline Wife earns less than husband & $\begin{array}{c}254.52 \\
(219.18)\end{array}$ & $\begin{array}{c}370.34 \\
(224.97)\end{array}$ & $\begin{array}{c}0.62 \\
(0.19)\end{array}$ & 356 \\
\hline Wife earns the same as husband & $\begin{array}{c}247.21 \\
(208.03)\end{array}$ & $\begin{array}{c}358.35 \\
(204.70)\end{array}$ & $\begin{array}{c}0.62 \\
(0.19)\end{array}$ & 308 \\
\hline Wife earns more than husband & 260.71 & 362.39 & 0.64 & 72 \\
\hline \multicolumn{5}{|c|}{ Minutes of childcare-routine } \\
\hline Wife earns less than husband & $\begin{array}{c}156.55 \\
(139.27)\end{array}$ & $\begin{array}{c}292.75 \\
(185.35)\end{array}$ & $\begin{array}{c}0.67 \\
(0.20)\end{array}$ & 356 \\
\hline Wife earns the same as husband & $\begin{array}{c}162.11 \\
(137.30)\end{array}$ & $\begin{array}{c}278.14 \\
(165.39)\end{array}$ & $\begin{array}{c}0.65 \\
(0.19)\end{array}$ & 308 \\
\hline Wife earns more than husband & $\begin{array}{c}163.56 \\
(152.49)\end{array}$ & $\begin{array}{c}276.71 \\
(164.96)\end{array}$ & $\begin{array}{l}0.67 \\
(0.21)\end{array}$ & 72 \\
\hline & \multicolumn{4}{|c|}{ Minutes of childcar-leisure } \\
\hline Wife earns less than husband & $\begin{array}{c}97.45 \\
(115.22)\end{array}$ & $\begin{array}{c}75.86 \\
(93.86)\end{array}$ & $\begin{array}{c}0.44 \\
(0.31)\end{array}$ & 356 \\
\hline Wife earns the same as husband & $\begin{array}{c}84.76 \\
(109.97)\end{array}$ & $\begin{array}{c}79.62 \\
(99.41)\end{array}$ & $\begin{array}{c}0.54 \\
(0.34)\end{array}$ & 308 \\
\hline Wife earns more than husband & $\begin{array}{c}96.97 \\
(116.11)\end{array}$ & $\begin{array}{c}80.83 \\
(91.75)\end{array}$ & $\begin{array}{c}0.47 \\
(0.29)\end{array}$ & 72 \\
\hline
\end{tabular}

Table 10 shows the results for the spouses' division of housework and childcare for households with children under 10 years old. Regarding housework, women earning more than their husbands do relatively more housework than those women earning the same than their husbands. I.e. as reported in Table 8 with respect to housework performed during the weekends, specialization within the household actually increases, and not decreases, with women's relative earnings. This again is consistent with the doing gender hypothesis. ${ }^{18}$

Turning to childcare we observe that the relative amount of time that spouses devote to routine childcare activities varies with respect to the wife's relative earnings. In fact, out of all explanatory variables used in the analysis only the wife's education and the number of members in the household seem to have some explanatory power.

\footnotetext{
${ }^{18}$ However, as in the pooled sample, we cannot reject the hypothesis that $\beta_{0}$ and $\beta_{1}$ are significantly different from each other. The last row of Table 10 shows that a Wald test for the null hypotehesis that $B_{0}=B_{1}$ cannot be rejected at the $90 \%$ level.
} 
These results are not likely to be due to small sample sizes (indeed, the regression results regarding housework specialization is very similar to those obtained when the sample of parents and non-parents was used). However, these results could be due to our definition of childcare-routine if we have failed to capture childcare conceptually closer to housework in our definition. We have constructed different definitions of childcare leisure and childcare routine, including or excluding secondary childcare and changing the classification. Results are robust to these different specifications. We have also used the sample of parents of the under- 5 and also consider the samples of week and weekend separately. Results are virtually the same. ${ }^{19}$

\section{Table 10}

Housework, childcare and relative earnings

\begin{tabular}{|c|c|c|c|c|c|c|c|}
\hline Wife's share of housework and childcare time & $\begin{array}{c}\text { Housework } \\
\text { (6) }\end{array}$ & (1) & (2) & $\begin{array}{l}\text { ildcare rout } \\
\text { (3) }\end{array}$ & ne & (5) & (6) \\
\hline wife earns same as husband & $\begin{array}{c}-0.100 \\
(4.68)^{\star \star \star}\end{array}$ & $\begin{array}{c}-0.01306 \\
(0.78)\end{array}$ & $\begin{array}{c}-0.01492 \\
(0.89)\end{array}$ & $\begin{array}{c}-0.01416 \\
(0.84)\end{array}$ & $\begin{array}{c}-0.00435 \\
(0.26)\end{array}$ & $\begin{array}{c}-0.00513- \\
(0.30)\end{array}$ & $\begin{array}{r}-0.00477 \\
(0.28)\end{array}$ \\
\hline wife earns more than husband & $\begin{array}{c}-0.084 \\
(2.28)^{\star \star}\end{array}$ & $\begin{array}{c}0.00122 \\
(0.04)\end{array}$ & $\begin{array}{c}0.00402 \\
(0.14)\end{array}$ & $\begin{array}{c}0.00454 \\
(0.16)\end{array}$ & $\begin{array}{c}0.01683 \\
(0.58)\end{array}$ & $\begin{array}{c}0.01633 \\
(0.55)\end{array}$ & $\begin{array}{r}0.01595 \\
(0.54)\end{array}$ \\
\hline household income between 1500 and $3000 \mathrm{E}$ & $\begin{array}{c}-0.035 \\
(1.22)\end{array}$ & & $\begin{array}{c}-0.01899 \\
(0.89)\end{array}$ & $\begin{array}{c}-0.02036 \\
(0.95)\end{array}$ & $\begin{array}{c}0.00554 \\
(0.25)\end{array}$ & $\begin{array}{c}0.00705 \\
(0.32)\end{array}$ & $\begin{array}{l}0.013 \\
(0.55)\end{array}$ \\
\hline household income higher than $3000 \mathrm{E}$ & $\begin{array}{l}0.024 \\
(0.60)\end{array}$ & & $\begin{array}{c}-0.02259 \\
(0.88)\end{array}$ & $\begin{array}{c}-0.02563 \\
(0.97)\end{array}$ & $\begin{array}{c}0.03715 \\
(1.24)\end{array}$ & $\begin{array}{c}0.04323 \\
(1.42)\end{array}$ & $\begin{array}{l}0.045 \\
(1.43)\end{array}$ \\
\hline wife's age & $\begin{array}{l}-0.009 \\
(2.34)^{* *}\end{array}$ & & & $\begin{array}{c}0.00199 \\
(0.70)\end{array}$ & $\begin{array}{c}0.00246 \\
(0.88)\end{array}$ & $\begin{array}{c}0.00259 \\
(0.92)\end{array}$ & $\begin{array}{l}0.001 \\
(0.48)\end{array}$ \\
\hline husbands age & $\begin{array}{l}0.001 \\
(0.48)\end{array}$ & & & $\begin{array}{c}-0.00168 \\
(0.69)\end{array}$ & $\begin{array}{c}-0.00212 \\
(0.88)\end{array}$ & $\begin{array}{c}-0.00236 \\
(0.97)\end{array}$ & $\begin{array}{r}-0.003 \\
(1.31)\end{array}$ \\
\hline wife's years of education & $\begin{array}{l}-0.001 \\
(0.36)\end{array}$ & & & & $\begin{array}{l}-0.00896 \\
(3.21)^{\star \star \star}\end{array}$ & $\begin{array}{l}-0.00924 \\
(3.27)^{\star \star \star}\end{array}$ & $\begin{array}{r}-0.008 \\
(2.70)^{\star \star \star}\end{array}$ \\
\hline husbands years of education & $\begin{array}{l}-0.001 \\
(0.41)\end{array}$ & & & & $\begin{array}{c}-0.00255 \\
(0.95)\end{array}$ & $\begin{array}{c}-0.00253 \\
(0.94)\end{array}$ & $\begin{array}{r}-0.001 \\
(0.46)\end{array}$ \\
\hline paid housekeeper & $\begin{array}{l}-0.039 \\
(1.16)\end{array}$ & & & & & & $\begin{array}{r}-0.006 \\
(0.24)\end{array}$ \\
\hline region dummies & yes & & & & & yes & yes \\
\hline number of members in the household & $\begin{array}{c}0.090 \\
(4.22)^{\star \star \star}\end{array}$ & & & & & & $\begin{array}{r}0.031 \\
(1.88)^{*}\end{array}$ \\
\hline household technology dummies & yes & & & & & & yes \\
\hline housework outsourcing dummies & yes & & & & & & yes \\
\hline Number of children under 15 & $\begin{array}{l}-0.036 \\
(1.39)\end{array}$ & & & & & & $\begin{array}{r}-0.011 \\
(0.56)\end{array}$ \\
\hline children under 4 years-old dummy & $\begin{array}{c}-0.055 \\
(3.04)^{\star \star \star}\end{array}$ & & & & & & $\begin{array}{r}-0.011 \\
(0.74)\end{array}$ \\
\hline week-day observation & $\begin{array}{c}0.098 \\
(4.50)^{\star * \star}\end{array}$ & $\begin{array}{l}0.10725 \\
(6.15)^{\star * \star}\end{array}$ & $\begin{array}{l}0.10723 \\
(6-14)^{\star * \star}\end{array}$ & $\begin{array}{l}0.10767 \\
(6.16)^{\star \star \star}\end{array}$ & $\begin{array}{l}0.10668 \\
(6.18)^{\star * \star}\end{array}$ & $\begin{array}{l}0.10744 \\
(6.22)^{\star \star \star}\end{array}$ & $\begin{array}{l}0.10746 \\
(6.18)^{\star \star *}\end{array}$ \\
\hline constant & $\begin{array}{c}0.795 \\
(6.72)^{\star \star *}\end{array}$ & $\begin{array}{r}0.59707 \\
(35.84)^{\star \star \star} \\
\end{array}$ & $\begin{array}{c}0.61381 \\
(25.30)^{\star \star \star} \\
\end{array}$ & $\begin{array}{l}0.60688 \\
(9.12)^{\star \star \star}\end{array}$ & $\begin{array}{c}0.71037 \\
(10.13)^{\star \star \star} \\
\end{array}$ & $\begin{array}{l}0.71571 \\
(9.88)^{\star \star \star} \\
\end{array}$ & $\begin{array}{r}0.69268 \\
(7.41)^{\star \star \star} \\
\end{array}$ \\
\hline $\begin{array}{l}\text { Observations } \\
\text { R-squared } \\
\text { p }>\text { F bO=b } 1\end{array}$ & $\begin{array}{c}736 \\
0.198 \\
0.51\end{array}$ & $\begin{array}{c}721 \\
0.302 \\
0.63\end{array}$ & $\begin{array}{c}721 \\
0.309 \\
0.52\end{array}$ & $\begin{array}{c}721 \\
0.314 \\
0.53\end{array}$ & $\begin{array}{c}721 \\
0.467 \\
0.47\end{array}$ & $\begin{array}{c}721 \\
0.558 \\
0.48\end{array}$ & $\begin{array}{r}721 \\
0.674 \\
0.49\end{array}$ \\
\hline
\end{tabular}

Tobit estimates (sample of parents of children under 10)

Significance levels: ${ }^{*} 10 \% ;{ }^{*}$ 5\%; - ${ }^{*} 1 \%$

\footnotetext{
${ }^{19}$ Available upon request.
} 


\subsection{Interpreting the Results}

The results presented herein have provided some evidence of social norms associated to the household division of labor. Consistent with other studies, our findings suggest that a woman's relative share of housework and childcare does not change with the spouses' relative earnings. This Section provides alternative explanations to this empirical regularity based on systematic differences in household production and tastes between women who earn more than their husbands and women who earn less. Ideally the use of panel data would solve these concerns as long as the heterogeneity is constant over time. However, to our knowledge, there is no recent panel data, that is a diary, and interview both members of the household. The last part of this section provides a possible interpretation of the results in light of social norms.

First, one might argue that women that earn more than their husbands might be less productive at home. Thus, keeping everything else constant, higher relative earning women might devote more time to housework in order to get the same output than women that earn less than their husbands. Although our specifications control for household production by including measures of household technology (such as the presence of a microwave) and household outsourcing (such as any helped received) these variables are imperfect measures and some unobserved heterogeneity with respect to women's productivity might not be accounted for. There is, however, big evidence in the literature that shows that more productive women in the market are also more productive at home, specially in childcare.

An alternative explanation consistent with our findings would be that women that earn more than their husbands have, everything else equal, a stronger taste for household produced goods and childcare than women that earn less than their husbands. Whereas we have tried to control for this heterogeneity in preferences using woman's education and age, there might still be some heterogeneity in tastes that is not accounted for.

Finally, another plausible explanation might have to do with the matching mechanism in the marriage market. It might be that women whose earnings are higher than their husbands marry to men that either have a higher taste for household produced goods and childcare, or that are less productive at doing housework or childcare. Under this scenario, and considering everything else constant including the total household produced output, women with higher relative earnings will have to compensate by doing a higher share of housework than women with relative lower earnings. We try to tackle this potential problem by controlling for husband's characteristics but this might still leave out some unobserved heterogeneity.

We could venture that the results obtained herein seem consistent with social norms characterized by an upper (lower) limit to the amount of housework that a man (woman) should do in a household. These social norms might become binding when commitment failures associated to the division of household labor exist. The literature has long recognized the presence of limited commitment problems within the household that may arise as a result of a couple's inability to either reach binding, legally-enforceable agreements about future behavior because of the non-observability by third parties (see (Basu, 2004) and (Rasul, 2002)) or to fulfill informal contracts because of the lack of credible threats, specially in caring activities (Folbre and Bittman, 2004). Although inefficient outcomes due to commitment failures seem plausible for decisions that arise repeatedly, such as situations in which "taking turns" is possible, even for repeated decisions economic theory offers no presumption of efficiency (Pollak, 2006). Imperfect commitment is usually characterized as the inability of one spouse to make transfers of private consumption to compensate the other partner for utility losses 
(Lundberg and Pollak, 2001). In this paper we have focused on the inability of partners to credibly commit to make transfers of time (leisure), rather than money.

\section{Conclusion}

The results presented in this paper have provided some evidence of social norms associated to the household division of labor. Economic theories of the household predict that increases in female human capital lead to increases in female labor force participation and, symmetrically, to decreases in the female time devoted to household production. We use the Spanish Time Use data 2002 to explore the nonlinearities associated to the division of housework.

Consistent with other studies, our findings suggest that a woman's relative share of housework and childcare does not change with the spouses' relative earnings. Moreover, during weekends, and for the sample of parents the relative amount of housework done by women who earn more than their husbands is higher than the relative amount of housework done by women who earn less than their husbands. This means that household specialization is actually increasing, not decreasing, with a woman's relative earnings. These findings are robust to different specifications of the regression equation, the sample used or the definition of housework and childcare.

We have interpreted our results as consistent with the theories of social norms and gender roles associated to the household division of labor. Although it is beyond of this paper to address how these social norms are formed, investigating how social norms that govern the allocation of family time are formed and sustained over time is certainly a topic worth pursuing in future research. 


\section{References}

Akerlof, G. and R. Kranton (2000), "Economics and Identity," Quarterly Journal of Economics, Vol. 115, Issue 3, pp. 715-753.

Aguiar, M. and E. Hurst (2006), "Measuring trends in Leisure: The allocation of time over five decades," NBER Working Paper no. 12082.

Alvarez and Miles (2003), "Gender effects on Housework Allocation: Evidence from Spanish two-earners couples," Journal of Population Economics, 16, pp. 277-242.

Basu, Kaushik (2004), "Gender and Say: A Model of Household Behavior with Endogenously-determined Balance of Power," Harvard Institute of Economic Research Discussion Paper No. 2054.

Becker, G. (1991), "A Treatise on the Family," Harvard University Press, Cambridge, Massachusetts.

Bianchi, Suzanne M. (2000), "Maternal employment and Time with Children: Dramatic Change or Surprising Continuity?," Demography, 37 (November), pp. 139-154.

Bianchi, S., V. Wight, and S. Raley (2006), "Maternal Employment and Family Caregiving: Rethinking Time with Children in the ATUS," ATUS Early Results Conference, Maryland.

Bittman, M., R. England, N. Folbre, L. Sayer and G. Matherson, (2001), ”When Gender Trumps Money: Bargaining and Time in Household Work," The American Journal of Sociology, 109, 1A, pp.186-214.

Bonke, J., N. D. Gupta, and N. Smith (2005), "The timing and flexibility of housework and men's and women's wages," in The Economic of Time Use, D.S. Hammermesh and G.A Pfann editors, Elsevier.

Brines, J. (1994), "Economic Dependancy, Gender, and the Division of Labor at Home," American Journal of Sociology, 100, pp. 652-688.

Browning and Chiappori (1997), "Efficient Intra-Household Allocations: A General Characterization and Empirical Tests," Econometrica, Vol. 66, No. 6 (November, 1998), pp. 1241-1278.

Burda, M., D. Hamermesh, and P. Weil (2006), ”Iso-Work and Social Norms” (mimeo).

Chiappori, P.A. (1992), "Collective Labor Supply and Welfare," The Journal of Political Economy, Vol. 100, Iss. 3., pp. 437-467.

De la Fuente, A. and J.F. Jimeno (2005), "The private and fiscal returns to chooling and the effect of public policies on private incentives to invest in education: a general framework and some results for the EU," working paper 0509 Bank of Spain.

Folbre N. and M. Bittman (2004), "Fan-Lily Time: The Social Organization of Care," Routledge, New York, NY.

Folbre, N., J. Yoon, K. Finoff, and A.S. Fuligni (2004), "By What Measure? Family Time Devoted to Children in the U. S.," Demography, Vol. 42, 2, May 2005, pp. 373-390. 
Greenstein, T. N. (2000), "Economic Dependence, Gender, and the Division of Labor in the Home: A Replication and Extension," Journal of Marriage and the Family, 62, pp. 322-335.

Gupta, S. (1999), "Gender Display? A reassessment of the Relationship between Men's Economic Dependence and Their Housework Hours," Paper presented at the annual meeting of the American Sociological Association, Chicago.

Hersch, Joni and Leslie S. Stratton (2000), "Household Specialization and the Male Marital Wage Premium," Industrial and Labor Relations Review, 54, No. 1, October, 2000 pp. 78-94.

Hochsehild and Machung (1989), "The Second Schift: Working Parents and the Revolution at Home," Viking, New York.

Juster, Thomas (1985), "The Validity and Quality of Time Use Estimates Obtained from Recall Diaries," in Thomas Juster and Frank Stafford (eds.), “Time, Goods, and Well-Being," Ann Arbor, Institute for Social Research, The University of Michigan.

Juster, T. and F. Stafford (1991), "The Allocation of Time: Empirical Findings, Behavioral Models, and Problems of Measurement," Journal of Economic Literature, Vol. 29, No. 2, pp. 471-522.

Lundberg, S. and R.A. Pollak (1993), "Separate Spheres Bargaining and the Marriage Market," Journal of Political Economy, 101, iss. 6, pp. 988-1010.

Lundberg, S. and R.A. Pollak (2001), "Efficiency in Marriage," NBER Working Paper 8642.

McElroy, M. and M.J. Horney (1981), "Nash-Bargained Household Decisions: Toward a Generalization of the Theory of Demand," International Economies Review, Vol. 22, Issue 2, pp. 333-349.

Pollak, Robert (2006), "Inefficiency in Families," Paper presented at the 20th Meeting of the European Society of Population Economics.

Rasul, I. (2002), "Household Bargaining Over Fertility: Theory and Evidence from Malaysia," working paper, London School of Economics.

Robinson, John (1985), "The Validity and Reliability of Diaries Versus Alternative Time Use Measures," in Thomas Juster and Frank Stafford (eds.), "Time, Goods, and Well-Being," Ann Arbor, Institute for Social Research, The University of Michigan. 


\section{A. Description of Housework Categories}

Table A.1.

Classification of activities in STUS

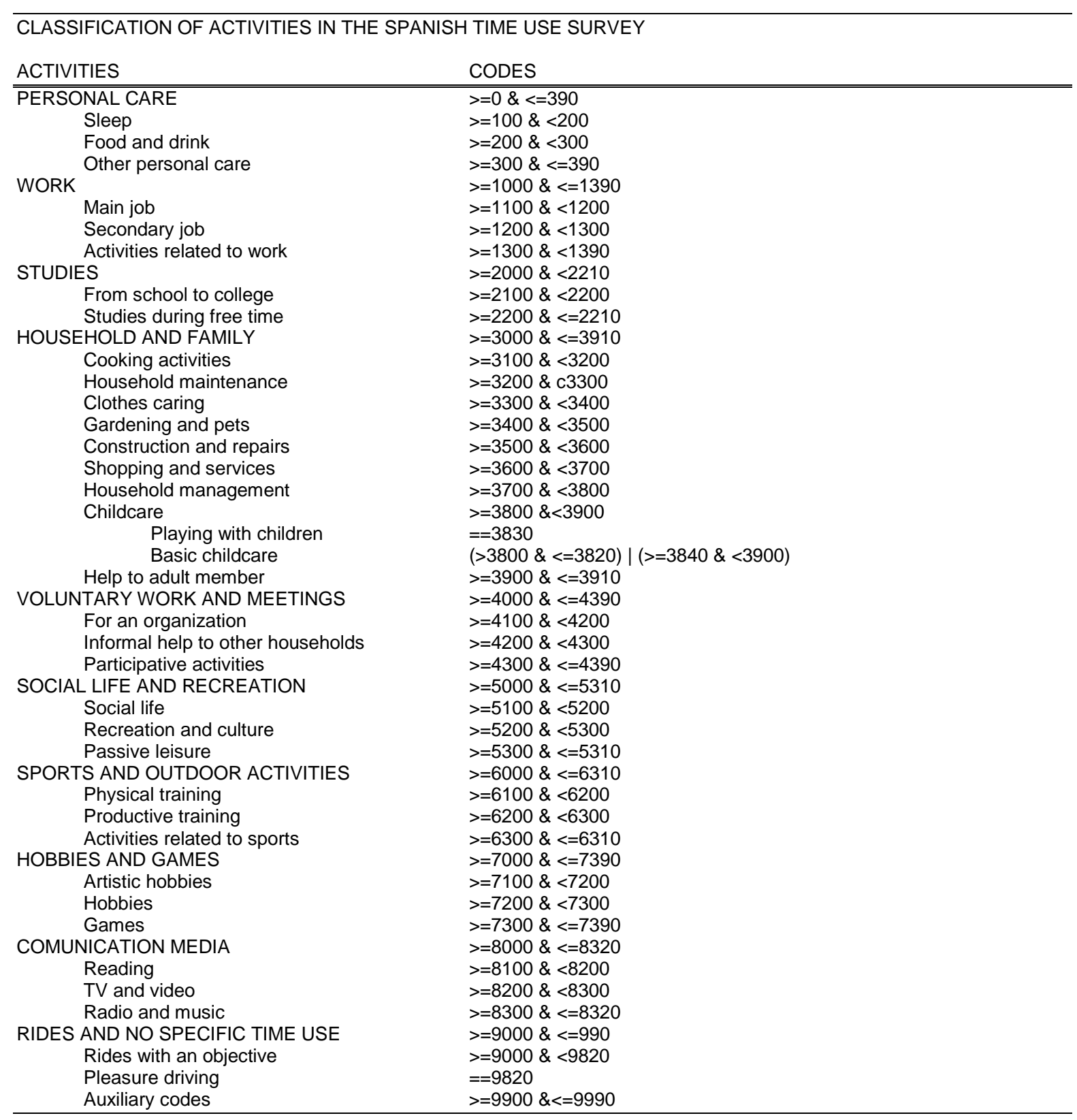




\section{B Activities in the presence of children under 10}

Table B.1.

Activities with children under 10

\begin{tabular}{lrrrrrr}
\hline & \multicolumn{3}{c}{ Husband } & \multicolumn{3}{c}{ Wife } \\
\hline \hline Activity & $\%$ & $\begin{array}{c}\text { Mean } \\
\text { (fraction } \\
\text { who report } \\
\text { time>0) }\end{array}$ & $\begin{array}{c}\text { Mean } \\
\text { (whole } \\
\text { sample) }\end{array}$ & $\begin{array}{c}\text { Mean } \\
\text { (fraction } \\
\text { who report } \\
\text { time>0) }\end{array}$ & $\begin{array}{c}\text { Mean } \\
\text { (whole } \\
\text { sample) }\end{array}$ \\
\hline Personal Care & $72.25 \%$ & 75.93 & 54.86 & $82.91 \%$ & 79.85 & 66.21 \\
Work & $2.87 \%$ & 80.01 & 2.30 & $4.08 \%$ & 102.72 & 4.19 \\
Studies & $0.86 \%$ & 75.28 & 0.65 & $0.43 \%$ & 18.93 & 0.08 \\
Household and Family & $71.89 \%$ & 115.88 & 83.30 & $92.15 \%$ & 189.78 & 174.88 \\
Voluntary Work and Meetings & $1.82 \%$ & 1.37 & 0.02 & $2.43 \%$ & 1.07 & 0.03 \\
Social Life and Recreation & $33.01 \%$ & 83.95 & 27.71 & $39.46 \%$ & 71.24 & 28.11 \\
Sports and Outdoor Activities & $18.55 \%$ & 85.19 & 15.80 & $20.90 \%$ & 74.20 & 15.51 \\
Hobbies and Games & $2.76 \%$ & 67.13 & 1.85 & $1.52 \%$ & 62.31 & 0.95 \\
Communication and Media & $37.60 \%$ & 78.87 & 29.66 & $27.75 \%$ & 68.23 & 18.93 \\
Travel and Unspecified Time Use & $49.84 \%$ & 45.65 & 22.75 & $70.52 \%$ & 47.84 & 33.74 \\
\hline \hline
\end{tabular}

Sample: Parents with children younger than 10 


\section{Conceptualization of Childcare as housework}

Table C.1.

Conceptualization of childcare

\begin{tabular}{|c|c|c|c|c|c|c|c|}
\hline \multirow{2}{*}{ Activity } & \multirow[b]{2}{*}{ Type } & \multicolumn{3}{|c|}{ Husband } & \multicolumn{3}{|c|}{ Wife } \\
\hline & & $\%$ & $\begin{array}{c}\text { Mean } \\
\text { (fraction } \\
\text { who report } \\
\text { time>0) }\end{array}$ & $\begin{array}{c}\text { Mean } \\
\text { (whole } \\
\text { sample) }\end{array}$ & $\%$ & $\begin{array}{c}\text { Mean } \\
\text { (fraction } \\
\text { who report } \\
\text { time>0) }\end{array}$ & $\begin{array}{c}\text { Mean } \\
\text { (whole } \\
\text { sample) }\end{array}$ \\
\hline PERSONAL CARE & $\mathbf{R}$ & $72.25 \%$ & 75.93 & 54.86 & $82.91 \%$ & 79.85 & 66.21 \\
\hline Sleep & $\mathrm{R}$ & $3.81 \%$ & 165.90 & 6.32 & $5.77 \%$ & 113.42 & 6.54 \\
\hline Food and drink & $\mathrm{R}$ & $69.42 \%$ & 64.11 & 44.51 & $80.23 \%$ & 65.76 & 52.76 \\
\hline Other personal care & $\mathrm{R}$ & $18.95 \%$ & 21.24 & 4.03 & $28.03 \%$ & 24.63 & 6.90 \\
\hline WORK & $\mathbf{R}$ & $2.87 \%$ & 80.01 & 2.30 & $4.08 \%$ & 102.72 & 4.19 \\
\hline Main job & $\mathrm{R}$ & $1.61 \%$ & 83.97 & 1.35 & $3.28 \%$ & 110.58 & 3.63 \\
\hline Secondary job & $\mathrm{R}$ & $0.64 \%$ & 122.59 & 0.78 & $0.29 \%$ & 120.00 & 0.35 \\
\hline Activities related to work & $\mathrm{R}$ & $0.62 \%$ & 25.90 & 0.16 & $0.58 \%$ & 50.70 & 0.29 \\
\hline STUDIES & $\mathbf{R}$ & $0.86 \%$ & 75.28 & 0.65 & $0.43 \%$ & 18.93 & 0.08 \\
\hline From school to college & $\mathrm{R}$ & $0.00 \%$ & 0.00 & 0.00 & $0.37 \%$ & 10.00 & 0.04 \\
\hline Studies during free time & $\mathrm{R}$ & $0.86 \%$ & 75.28 & 0.65 & $0.06 \%$ & 70.00 & 0.04 \\
\hline HOUSEHOLD AND FAMILY & & $71.89 \%$ & 115.88 & 83.30 & $92.15 \%$ & 189.78 & 174.88 \\
\hline Cooking activities & $\mathrm{R}$ & $36.56 \%$ & 32.38 & 11.84 & $66.73 \%$ & 50.91 & 33.97 \\
\hline Household maintenance & $\mathrm{R}$ & $14.33 \%$ & 39.49 & 5.66 & $39.12 \%$ & 45.25 & 17.70 \\
\hline Clothes caring & $\mathrm{R}$ & $2.84 \%$ & 17.82 & 0.51 & $20.93 \%$ & 44.26 & 9.26 \\
\hline Gardening and pets & L & $2.49 \%$ & 64.13 & 1.60 & $2.05 \%$ & 37.14 & 0.76 \\
\hline Construction and repairs & $\mathrm{R}$ & $1.23 \%$ & 51.98 & 0.64 & $1.26 \%$ & 27.13 & 0.34 \\
\hline Shopping and services & $\mathrm{R}$ & $12.85 \%$ & 54.05 & 6.94 & $26.14 \%$ & 54.86 & 14.34 \\
\hline Household management & $\mathrm{R}$ & $0.24 \%$ & 18.51 & 0.04 & $0.59 \%$ & 17.60 & 0.10 \\
\hline Childcare & & $62.33 \%$ & 86.10 & 53.66 & $83.82 \%$ & 113.05 & 94.76 \\
\hline Playing with children & $\mathrm{L}$ & $27.70 \%$ & 55.98 & 15.51 & $27.60 \%$ & 52.33 & 14.44 \\
\hline Basic childcare & $\mathrm{R}$ & $57.22 \%$ & 66.68 & 38.16 & $82.11 \%$ & 97.80 & 80.31 \\
\hline Help to adult members & $\mathrm{R}$ & $0.88 \%$ & 70.55 & 0.62 & $0.56 \%$ & 15.23 & 0.09 \\
\hline VOLUNTARY WORK AND MEETING: & $\mathbf{R}$ & $1.82 \%$ & 1.37 & 0.02 & $2.43 \%$ & 1.07 & 0.03 \\
\hline For an organization & $\mathrm{R}$ & $0.00 \%$ & 0.00 & 0.00 & $0.00 \%$ & 0.00 & 0.00 \\
\hline Informal help to other households & $\mathrm{R}$ & $0.55 \%$ & 62.88 & 0.35 & $1.51 \%$ & 36.42 & 0.55 \\
\hline Participative activities & $\mathrm{R}$ & $1.28 \%$ & 53.33 & 0.68 & $0.92 \%$ & 51.37 & 0.47 \\
\hline SOCIAL LIFE AND RECREATION & & $33.01 \%$ & 83.95 & 27.71 & $39.46 \%$ & 71.24 & 29.11 \\
\hline Social life & L & $22.43 \%$ & 68.55 & 15.37 & $28.84 \%$ & 59.80 & 17.25 \\
\hline Recreation and culture & L & $2.51 \%$ & 86.80 & 2.18 & $2.48 \%$ & 82.33 & 2.04 \\
\hline Passive leisure & L & $10.46 \%$ & 84.09 & 8.80 & $13.28 \%$ & 66.45 & 8.82 \\
\hline SPORTS AND OUTDOOR ACTIVITIES & & $18.55 \%$ & 85.19 & 15.80 & $20.90 \%$ & 74.20 & 15.51 \\
\hline Physical training & L & $18.09 \%$ & 84.98 & 15.37 & $20.49 \%$ & 74.75 & 15.32 \\
\hline Productive training & L & $0.06 \%$ & 150.00 & 0.09 & $0.06 \%$ & 150.00 & 0.09 \\
\hline Activities related to sports & $\mathrm{L}$ & $0.00 \%$ & 0.00 & 0.00 & $0.36 \%$ & 29.32 & 0.11 \\
\hline HOBBIES AND GAMES & & $2.76 \%$ & 67.13 & 1.85 & $1.52 \%$ & 62.31 & 0.95 \\
\hline Artistic hobbies & $\mathrm{R}$ & $0.03 \%$ & 120.00 & 0.04 & $0.00 \%$ & 0.00 & 0.00 \\
\hline Hobbies & $\mathrm{R}$ & $1.95 \%$ & 60.80 & 1.19 & $0.94 \%$ & 52.50 & 0.49 \\
\hline Games & $\mathrm{L}$ & $0.91 \%$ & 69.58 & 0.63 & $0.59 \%$ & 77.97 & 0.46 \\
\hline COMUNICATION MEDIA & & $37.60 \%$ & 78.87 & 29.66 & $27.75 \%$ & 68.23 & 18.93 \\
\hline Reading & $\mathrm{R}$ & $3.20 \%$ & 39.98 & 1.28 & $3.40 \%$ & 46.72 & 1.59 \\
\hline TV and video & $\mathrm{L}$ & $35.29 \%$ & 79.68 & 28.12 & $25.92 \%$ & 66.51 & 17.24 \\
\hline Radio and music & $\mathrm{R}$ & $0.88 \%$ & 29.40 & 0.26 & $0.12 \%$ & 92.26 & 0.11 \\
\hline RIDES AND NO SPECIFIC TIME USE & & $49.84 \%$ & 45.65 & 22.75 & $70.52 \%$ & 47.84 & 33.74 \\
\hline Rides with an objective & $\mathrm{R}$ & $49.46 \%$ & 44.54 & 22.03 & $70.40 \%$ & 47.19 & 33.22 \\
\hline Pleasure driving & $\mathrm{L}$ & $0.43 \%$ & 82.81 & 0.36 & $0.15 \%$ & 114.59 & 0.17 \\
\hline Auxiliary codes & $\mathrm{R}$ & $1.23 \%$ & 29.95 & 0.37 & $0.96 \%$ & 34.91 & 0.34 \\
\hline
\end{tabular}

